九州大学学術情報リポジトリ

Kyushu University Institutional Repository

\title{
Alleviation of High Temperature Stress in Wax Begonia (Begonia $\times$ semperflorens-cultorum Hort.) by Salicylic Acid
}

Lin, Ling-Na

Department of Horticulture, National Taiwan University, Taipei, Taiwan, Republic of China

Huang, Kuang Liang

Department of Horticulture, National Chiayi University, Chiayi, Taiwan, Republic of China

Okubo, Hiroshi

九州大学大学院農学研究院環境農学部門農業環境科学園芸学研究室

Chang, Yu-Sen

Department of Applied Biology, College of Agriculture and Life Science, Chungnam National University

https://doi.org/10.5109/20308

出版情報 : 九州大学大学院農学研究院紀要. 56 (2)，pp.193-198，2011-09. Faculty of Agriculture， Kyushu University

バージョン :

権利関係 : 


\title{
Alleviation of High Temperature Stress in Wax Begonia (Begonia $\times$ semperflorens-cultorum Hort.) by Salicylic Acid
}

\author{
Ling-Na LIN ${ }^{1}$, Kuang Liang HUANG ${ }^{2}$, Hiroshi OKUBO \\ and Yu-Sen CHANG ${ }^{1 *}$ \\ Laboratory of Horticultural Science, Division of Agronomy and Environmental Sciences, \\ Department of Agro-environmental Sciences, Faculty of Agriculture, \\ Kyushu University, Fukuoka 812-8581, Japan \\ (Received December 14, 2010 and accepted January 14, 2011)
}

\begin{abstract}
Wax begonia (Begonia $\times$ semperflorens-cultorum Hort.) plants often suffer from high temperature stress during hot seasons in Taiwan. Since salicylic acid (SA) has proved to enhance heat tolerance in many plants, this study evaluates whether exogenous SA applications could alleviate high temperature stress of wax begonias.

Plug seedlings of wax begonia 'Super Olympia' were treated with 25, 100, 400, 800, with $1600 \mu \mathrm{M}$ SA before $55^{\circ} \mathrm{C}$, for $2 \mathrm{~h}$ of high temperature stress. Results indicated that 25-400 $\mu \mathrm{M}$ SA enhanced heat tolerance by reducing the value of Relative Injury (RI) and Malondialdehyde (MDA), whereas 800, $1600 \mu \mathrm{M}$ SA had adverse effects. Transplanted plants of wax begonia 'Super Olympia' were treated with 25, 100, $400 \mu \mathrm{M}$ $\mathrm{SA}$ before $35^{\circ} \mathrm{C}$, for 16 days of high temperature stress. Results showed that $25-400 \mu \mathrm{M}$ SA enhanced heat tolerance by maintaining a higher value of Chlorophyll Meter Reading (CMR), reducing leaf thickness and the number of red spotted leaves. Especially, $100 \mu \mathrm{M}$ SA treatment had most significant improvement among 25-400 $\mu \mathrm{M}$ SA treatments.

The thermo protection period of $100 \mu \mathrm{M}$ SA maintained significantly for 5 days, based on the lower value of F0, RI, and MDA, and the higher value of Fm and Fv/Fm. Applying times up to 2 or 3 times extended protective effect significantly, based on reducing the value of RI and MDA, and increasing plant height and number of flowers. Either medium drench or foliar spray treatments improved heat tolerance of wax begonias. Medium drench treatments produced better thermo protection based on the results of higher Fm and Fv/Fm value. In conclusion, salicylic acid pretreatments with satisfactory concentrations between 25 to $400 \mu \mathrm{M}$ proved to enhance heat tolerance in the wax begonia. Results recommend medium drench with $100 \mu \mathrm{M}$ SA per week, up to 2-3 times as the most optimal application of SA.
\end{abstract}

\section{INTRODUCTION}

Wax begonia (fibrous-rooted begonia, Begonia $\times$ semperflorens-cultorum Hort.) is popular and widely grown for outdoor use in landscapes and gardens. Hamrick (2003) recommended a $\left(18-21 / 16-18^{\circ} \mathrm{C}\right)$ day/ night temperature as optimum for wax begonia growth and development. However, Taipei International Flora Exposition has raised the issue of extending plant vigor easily and economically, especially in the hot season.

Salicylic acid (SA) is a phenolic derivative, distributed in a wide range of plant species. In terms of stress physiology, salicylic acid has demonstrated an important role in response to biotic stress. Many reports have suggested that salicylic acid also plays a role in responses to abiotic stress (such as low or high temperature, UV-B irradiation, ozone, and heavy metals) (Hayat and Ahmad, 2007; Janda et al., 2007).

Dat et al. (1998a) first revealed that $1-100 \mu \mathrm{M} \mathrm{SA}$ could induce heat tolerance of mustard plants. Many researchers have indicated the protective effect of exogenous salicylic acid against high temperature stress in mustard plants (Dat et al., 1998a), potato microplants

\footnotetext{
Department of Horticulture, National Taiwan University, Taipei, Taiwan, Republic of China

2 Department of Horticulture, National Chiayi University, Chiayi, Taiwan, Republic of China

* Corresponding author (E-mail: yschang@ntu.edu.tw)
}

(Lopez et al., 1998), Arabidopsis (Larkindale and Knight, 2002), Cicer arietinum L. (Chakraborty and Tongden, 2005), creeping bentgrass (Agrostis stolonifera) (Larkindale and Huang, 2004), Kentucky bluegrass (Poa pratensis) (He et al., 2005), grape and citrus (Wang et al., 2002, 2003).

This research evaluates whether exogenous SA treatments enhance heat tolerance of 'Super Olympia' series wax begonias under various high temperature stress conditions. Trials were conducted on different plant growth stages, SA doses, applying methods, and times to provide simple, practical advice for application.

\section{MATERIALS AND METHODS}

\section{Plant materials}

Plug seedlings and transplants in $12-\mathrm{cm}$ diameter pots of wax begonia (Begonia $\times$ semperflorens-cultorum Hort.) 'Super Olympia' Series, including white, pink, and red cultivars were used in the experiment.

\section{Heat treatments}

Plants were subjected to various high temperature stresses $\left(35 / 30{ }^{\circ} \mathrm{C}\right.$ day/night temperature, phytotron of National Taiwan University up to or more than 14 days, or a $45{ }^{\circ} \mathrm{C}$ water bath for 20 mins, or $55^{\circ} \mathrm{C}$ preheated oven, dark, 2 hrs) to evaluate the SA effect.

\section{Exogenous SA treatments}


Plants were subjected to various concentrations (25-1600 $\mu \mathrm{M}$, adjusted to $\mathrm{pH} 6.8$ with $\mathrm{KOH}$ ) by medium drench or foliar spray to evaluate SA effect.

\section{Measurement items}

Number of leaves with red spots

Heat injury in leaves was evaluated visually by numbers of leaves with red spots. Data was collected by classifying the red spot area by the following criterion, then calculating the number of leaves at the end of the test.

The degrees of heat tolerance were measured according to the criterion with four grades as follows:

level 0 : the ratio of (red spot area/leaf area) $=0$ or $\leq 5 \%$.

level 1: the ratio of (red spot area/leaf area) $=5$ or $\leq 30 \%$

level 2: the ratio of (red spot area/leaf area) $=30$ or $\leq 60 \%$

level 3: the ratio of (red spot area/leaf area $)=>60 \%$

\section{Malondialdehyde (MDA)}

The extent of lipid peroxidation was estimated by determining MDA reacting to TBA (thiobarbituric acid)reactive substance. Leaves were sampled and followed the method of Yang et al. (2008).

\section{RI (Relative Injury value, \%)}

Twenty leaf discs (10 $\mathrm{mm}$ in diameter) were placed in $30 \mathrm{ml}$ glass vials, rinsed three times with $20 \mathrm{ml}$ of distilled water to remove electrolytes released during leaf disc excision. Vials were then filled with $30 \mathrm{ml}$ of distilled water and allowed to stand in the dark for $24 \mathrm{~h}$ at room temperature.

Electrical conductivity (EC1) of the bathing solution was determined at the end of the incubation period. Tubes were heated in a temperature-controlled water bath at $95{ }^{\circ} \mathrm{C}$ for $20 \mathrm{~min}$, and then cooled to room temperature for measuring the electrical conductivity (EC2). Electrolyte leakage was calculated as a percentage of EC1/EC2.

RI (Relative Injury value, \%) $=($ EC1/EC2 $) \times 100$ Shi et al. (2006).

\section{Chlorophyll fluorescence parameters}

Leaf photochemical efficiency was determined by measuring chlorophyll fluorescence. Chlorophyll fluorescence parameters were measured using a portable fluorometer (Mini-Pam, Walz Co., Germany). Leaves were dark acclimated for $30 \mathrm{~min}$ and the measurements of maximal quantum yield of PSII (Fv/Fm), minimal fluorescence $(\mathrm{F} 0)$, maximal fluorescence $(\mathrm{Fm})$ were carried out according to the method of Shi et al. (2006).

Chlorophyll meter reading (CMR value, SPAD-502 value)

CMR value was measured using the SPAD-502 chlorophyll meter (SPAD-502, Minolta Camera Co., Japan). This measures absorption at 650 and $940 \mathrm{~nm}$ wavelengths to estimate chlorophyll levels. Two measurements were immediately taken per leaf and averaged to provide a single value per leaf. The SPAD sensor was placed randomly on leaf mesophyll tissue only, avoiding veins.

Leaf thickness

Leaf thickness was measured using the sensor (SM112, Dial Thickness Gauges, Dogger Instrument Co., Taiwan). Two measurements were immediately taken per leaf and averaged to provide a single value per leaf. The sensor was placed randomly on leaf mesophyll tissue only, avoiding veins.

\section{Plant width}

Two measurements were taken, the biggest and smallest width per plant and averaged to provide a single value per plant.

\section{Statistics}

Values presented were means \pm one standard deviation (SD) of 5-7 replicates. Statistical analyses were carried out by analysis of variance (ANOVA). Differences between treatments were separated by the least significant difference (LSD) test at a 0.05 probability level.

\section{Application of treatments and evaluations}

Identifying optimal concentration of SA to enhance heat tolerance in wax begonia plug seedlings

Plug seedlings were foliar sprayed with salicylic acid solutions (100, 200, 400, 800, and $1600 \mu \mathrm{M}$ ), and with distilled water to act as a control. All seedlings were kept at room temperature for $2 \mathrm{~h}$. Seedlings were then exposed to high temperature $\left(55^{\circ} \mathrm{C}\right)$ for $2 \mathrm{~h}$. Following the high temperature treatment, leaves were sampled for RI and MDA analysis.

Treatments included five replicates, and one seedling per replicate.

\section{Identifying optimal concentration of SA to enhance heat tolerance in wax begonia transplants \\ Transplants were medium drenched with salicylic acid solutions $(25,100,400 \mu \mathrm{M})$, and in distilled water to act as a control. All plants were kept at room temper- ature for $2 \mathrm{~h}$ and then exposed to high temperature $\left(35 / 30{ }^{\circ} \mathrm{C}\right.$ day/night temperature phytotron) for 16 days. Following high temperature treatment, the measure- ments of plant height, width, CMR value, leaf thickness, number of leaves with red spots were recorded and ana- lyzed.}

Identifying the lasting period of SA for thermo protective effect

Transplants were foliar sprayed with $100 \mu \mathrm{M}$ salicylic acid, and in distilled water to act as a control. All plants were kept at room temperature for $2 \mathrm{~h}$ and then exposed to high temperature $\left(35 / 30^{\circ} \mathrm{C}\right.$ day/night temperature phytotron) for $1,2,3,4,5,6,7$ days. Chlorophyll fluorescence parameters were measured every day, then leaves were sampled for RI and MDA analysis.

Identifying optimal applying times of SA for thermo protective effect

Transplants were medium drenched with $100 \mu \mathrm{M}$ sali- 
cylic acid, and in distilled water to act as a control. All plants were kept at room temperature for $2 \mathrm{~h}$ and then exposed to high temperature $\left(35 / 30{ }^{\circ} \mathrm{C}\right.$ day/night temperature phytotron). The applying times were increased at 7-day intervals. At the end of the test, plant height, width, and flower numbers were recorded, and leaves were sampled for RI and MDA analysis.

SA thermo protective effect when comparing foliar spray treatment with medium drench treatment

Transplants were medium drenched or foliar sprayed with $100 \mu \mathrm{M}$ salicylic acid, and drenched in distilled water to act as a control. All plants were kept at room temperature for $2 \mathrm{~h}$ and then exposed to high temperature stress $\left(35 / 30{ }^{\circ} \mathrm{C}\right.$ day/night temperature phytotron) 14 days. Chlorophyll fluorescence parameters were measured.

\section{RESULTS}

\section{Identifying optimal concentration of SA to enhance} heat tolerance in wax begonia plug seedlings

Relative Injury value indicated that the dose of 100 $400 \mu \mathrm{M}$ of SA pretreatments significantly enhanced heat tolerance of plug seedlings by reducing electrolyte leakage and conferring membrane protection, while the higher concentration $(800,1600 \mu \mathrm{M})$ had opposite effect. Both $\mathrm{RI}$ values were higher than the control values (Fig. 1).

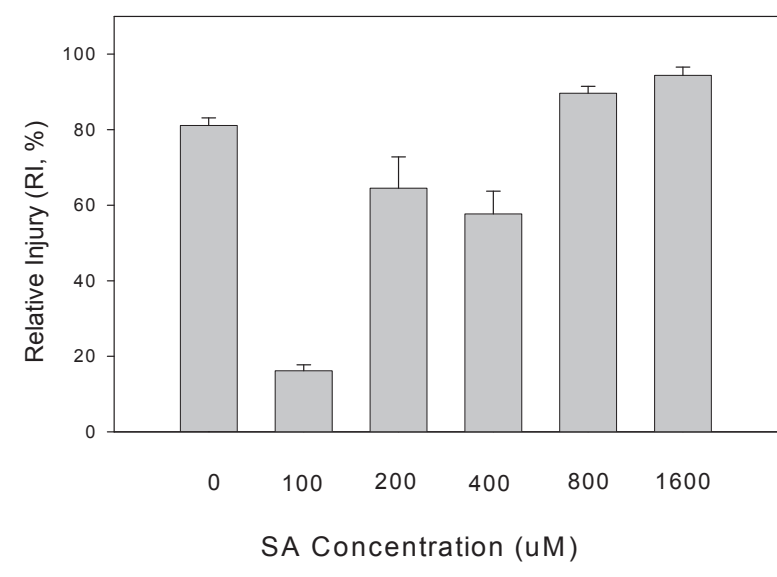

Fig. 1. Effects of various concentrations of SA pretreatment and heat shock $\left(55^{\circ} \mathrm{C}\right.$, dark, 2 hrs $)$ treatment on $\mathrm{RI}$ value (\%) of wax begonia.
MDA (Malondialdehyde) value showed that the dose of 100-200 $\mu \mathrm{M}$ of SA pretreatments reduced, compared with the control treatment, while the higher concentration $(800,1600 \mu \mathrm{M})$ had significant adverse effect (Fig. 2).

Pretreatment of wax begonia seedling leaves with SA solution $(100,200,400 \mu \mathrm{M})$ prior to high temperature stress significantly decreased electrolyte leakage, while the SA solution $(100,200 \mu \mathrm{M})$ pretreatment significantly decreased malondialdehyde production in the leaves. The recommended concentration of exogenous SA to enhance heat tolerance of wax begonia plug seedlings was not too high.

\section{Identifying optimal concentration of SA to enhance heat tolerance in wax begonia transplants}

The number of leaves with red spots showed that the dose of $25-400 \mu \mathrm{M}$ of SA pretreatments significantly decreased the appearance of red spot level 3 (Table 1).

$100 \mu \mathrm{M}$ of SA pretreatment by medium drench had the highest significant value of plant width and SPAD 502 value. 100, $400 \mu \mathrm{M}$ of SA medium drench decreased leaf thickness significantly (Table 1).

Results of the experiment of wax begonia transplants, showed better visual quality, higher width, and CMR (SPAD-502) value than the control, especially the $100 \mu \mathrm{M}$ pretreatment before high temperature stress $\left(35 / 30{ }^{\circ} \mathrm{C}\right.$

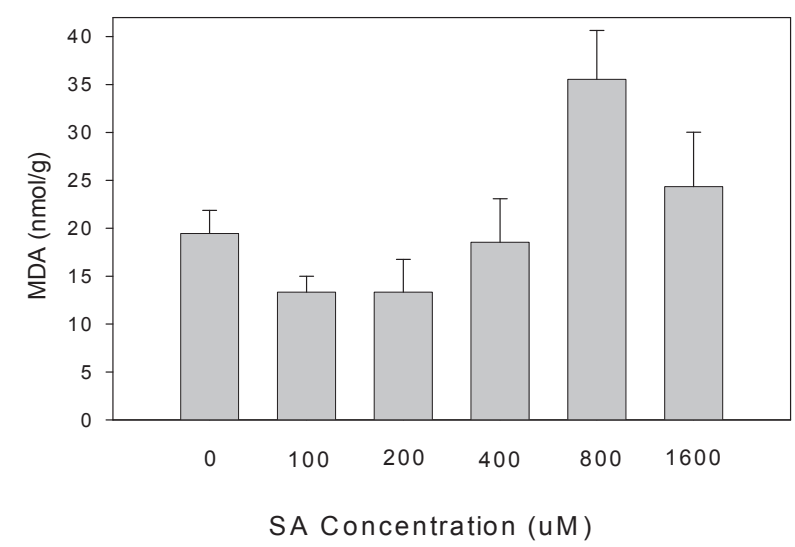

Fig. 2. Effects of various concentrations of SA pretreatment and heat shock $\left(55^{\circ} \mathrm{C}\right.$, dark, $\left.2 \mathrm{hrs}\right)$ treatment on MDA value (nmol/g) of wax begonia.

Table 1. Effects of various concentrations of salicylic acid pretreatment by medium drench and heat shock $\left(35 / 30{ }^{\circ} \mathrm{C}\right.$ day/night temperature Phytotron, 16 days) on plant growth and development of wax begonia 'Super Olympia' transplants

\begin{tabular}{|c|c|c|c|c|c|c|c|c|}
\hline \multirow{2}{*}{$\begin{array}{l}\text { Salicylic } \\
\text { acid }(\mu \mathrm{M})\end{array}$} & \multirow{2}{*}{$\begin{array}{l}\text { Plant height } \\
(\mathrm{cm})\end{array}$} & \multirow{2}{*}{$\begin{array}{l}\text { Plant width } \\
\text { (cm) }\end{array}$} & \multirow{2}{*}{$\begin{array}{l}\text { CMR SPAD-502 } \\
\text { value }\end{array}$} & \multirow{2}{*}{$\begin{array}{l}\text { Leaf thickness } \\
\text { (mm) }\end{array}$} & \multicolumn{4}{|c|}{ Number of leaves with red spots } \\
\hline & & & & & Level 0 & Level 1 & Level 2 & Level 3 \\
\hline 0 & 13.3 & 15.7 & 20.0 & 0.55 & 25.3 & 18.8 & 5.2 & 1.4 \\
\hline 25 & 14.3 & 12.5 & 21.0 & 0.53 & 21.6 & 18.8 & 4.0 & 0 \\
\hline 100 & 13.7 & 16.0 & 25.1 & 0.51 & 35.6 & 19.6 & 4.4 & 0 \\
\hline 400 & 16.4 & 14.6 & 20.4 & 0.50 & 41.8 & 15.4 & 3.6 & 0 \\
\hline LSD. 05 & 2.86 & 2.55 & 2.49 & 0.037 & 19.64 & - & - & 0.60 \\
\hline Significance & NS & $*$ & $* * *$ & $*$ & NS & NS & NS & $* * *$ \\
\hline
\end{tabular}


day/night temperature phytotron, 16 days).

\section{Identifying the lasting period of SA for thermo pro- tective effect}

Chlorophyll fluorescence parameters were measured after $100 \mu \mathrm{M}$ of SA foliar spray and high temperature

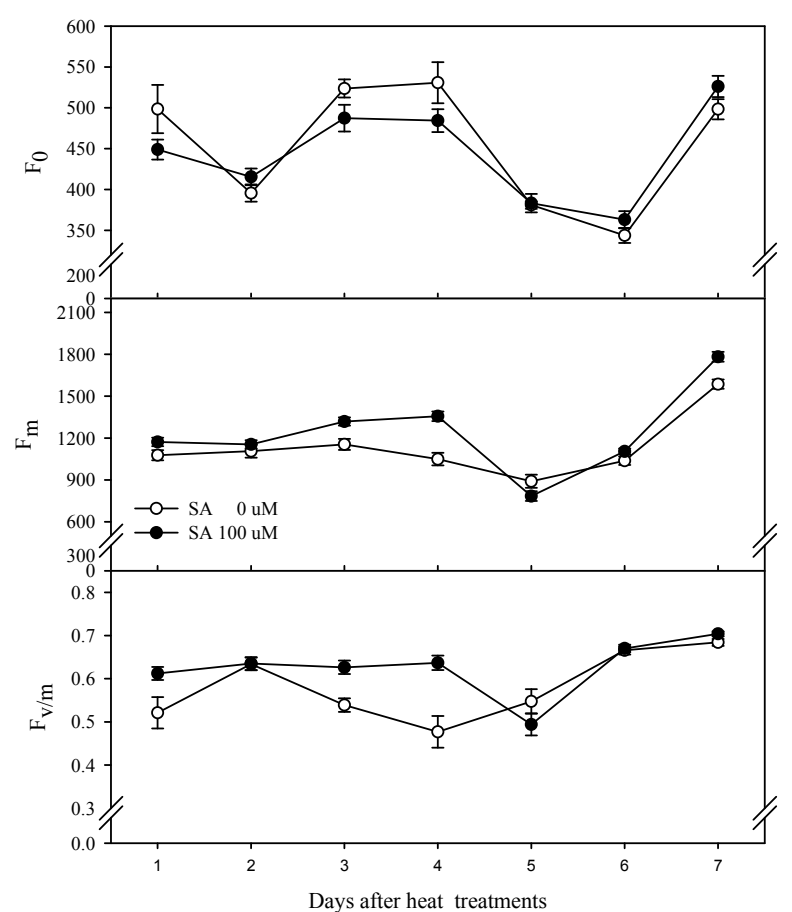

Fig. 3. Effects of salicylic acid treatment by foliar spray on chlorophyll fluorescence parameters of wax begonia on 'Super Olympia' plants under $40-35 / 30{ }^{\circ} \mathrm{C}$. stress in the first week. During 1-4 days, salicylic acid pretreatment plants showed a lower F0 value, and Fm, $\mathrm{Fv} / \mathrm{Fm}$ were higher than the control treatment plants (Fig. 3).

The RI values of SA $100 \mu \mathrm{M}$ pretreatment by foliar spray were less than the ones of the control treatment plants during the first five days, though not significant.

The MDA values of SA $100 \mu \mathrm{M}$ pretreatment by foliar spray were less than the ones of the control treatment plants on the first, third, and seventh day, though not significant (Table 2).

The values of chlorophyll fluorescence, RI, and MDA suggested that the protective effect could maintain about five days after SA $100 \mu \mathrm{M}$ foliar spray.

\section{Identifying the optimal applying times of SA for thermo protective effect}

SA $100 \mu \mathrm{M}$ pretreatment once by medium drench enhanced heat tolerance of wax begonia plants, based on the lower value of RI and MDA, compared with the control treatment plants.

The applying times of up to two or three times at 7-day intervals significantly decreased the value of RI. The result indicated that plant height and the number of flowers increased while applying times increased (Table $3)$.

\section{SA thermo protective effect compared to foliar spray treatment with the medium drench treatment}

Chlorophyll fluorescence parameters were measured after $100 \mu \mathrm{M}$ of SA foliar spray and medium drench before high temperature stress $\left(35 / 30{ }^{\circ} \mathrm{C}\right.$ day/night temperature phytotron, 14 days). Compared with the control treat-

Table 2. Effects of salicylic acid pretreatment by foliar spray on RI and MDA value of wax begonia 'Super Olympia' plants under $40-35 / 30{ }^{\circ} \mathrm{C}$

\begin{tabular}{llcccc}
\hline & Treatment & 1st day & 3rd day & 5th day & 7 th day \\
\hline RI (\%) & CK & $11.11 \mathrm{a}^{\mathrm{z}}$ & $8.64 \mathrm{a}$ & $16.78 \mathrm{a}$ & $10.30 \mathrm{a}$ \\
& SA $100 \mu \mathrm{M}$ & $8.81 \mathrm{a}$ & $8.49 \mathrm{a}$ & $14.84 \mathrm{a}$ & $12.89 \mathrm{a}$ \\
\hline \multirow{2}{*}{ MDA (nmol/g) } & CK & $9.00 \mathrm{a}$ & $11.89 \mathrm{a}$ & $13.43 \mathrm{a}$ & $16.07 \mathrm{a}$ \\
& SA $100 \mu \mathrm{M}$ & $8.28 \mathrm{a}$ & $10.71 \mathrm{a}$ & $14.69 \mathrm{a}$ & $14.85 \mathrm{a}$ \\
\hline
\end{tabular}

${ }^{z}$ Mean separation within columns by LSD test, $\mathrm{P}<0.05$

Table 3. Effects of various applying times of salicylic acid pretreatment by medium drench on growth and injury of wax begonia 'Super Olympia' plants under high temperature stress $\left(40-35 / 30{ }^{\circ} \mathrm{C}\right.$ day/night temperature Phytotron, 28days)

\begin{tabular}{lccccc}
\hline Treatment & $\begin{array}{c}\text { RI } \\
(\%)\end{array}$ & $\begin{array}{c}\text { MDA } \\
(\mathrm{nmol} / \mathrm{g})\end{array}$ & $\begin{array}{c}\text { Plant height } \\
(\mathrm{cm})\end{array}$ & $\begin{array}{c}\text { Plant width } \\
(\mathrm{cm})\end{array}$ & $\begin{array}{c}\text { Number of } \\
\text { flowers }\end{array}$ \\
\hline Control & $9.38 \mathrm{a}^{\mathrm{z}}$ & $0.99 \mathrm{a}$ & $15.1 \mathrm{~b}$ & $18.6 \mathrm{a}$ & $13.5 \mathrm{~b}$ \\
SA, once & $7.98 \mathrm{~b}$ & $0.86 \mathrm{~b}$ & $15.2 \mathrm{~b}$ & $18.2 \mathrm{a}$ & $12.6 \mathrm{~b}$ \\
SA, 2 times & $7.21 \mathrm{bc}$ & $0.82 \mathrm{bc}$ & $16.4 \mathrm{ab}$ & $17.1 \mathrm{a}$ & $21.4 \mathrm{a}$ \\
SA, 3 times & $6.56 \mathrm{c}$ & $0.71 \mathrm{c}$ & $17.0 \mathrm{a}$ & $18.3 \mathrm{a}$ & $24.6 \mathrm{a}$ \\
\hline
\end{tabular}

Each value is the mean of five replications.

${ }^{2}$ Mean separation within columns by LSD test, $\mathrm{P}<0.05$ 
ment plants; both foliar spray and medium drench significantly lowered the value of F0, and raised the value of Fv/Fm. The result indicated that either foliar spray or medium drench could enhance the tolerance of wax

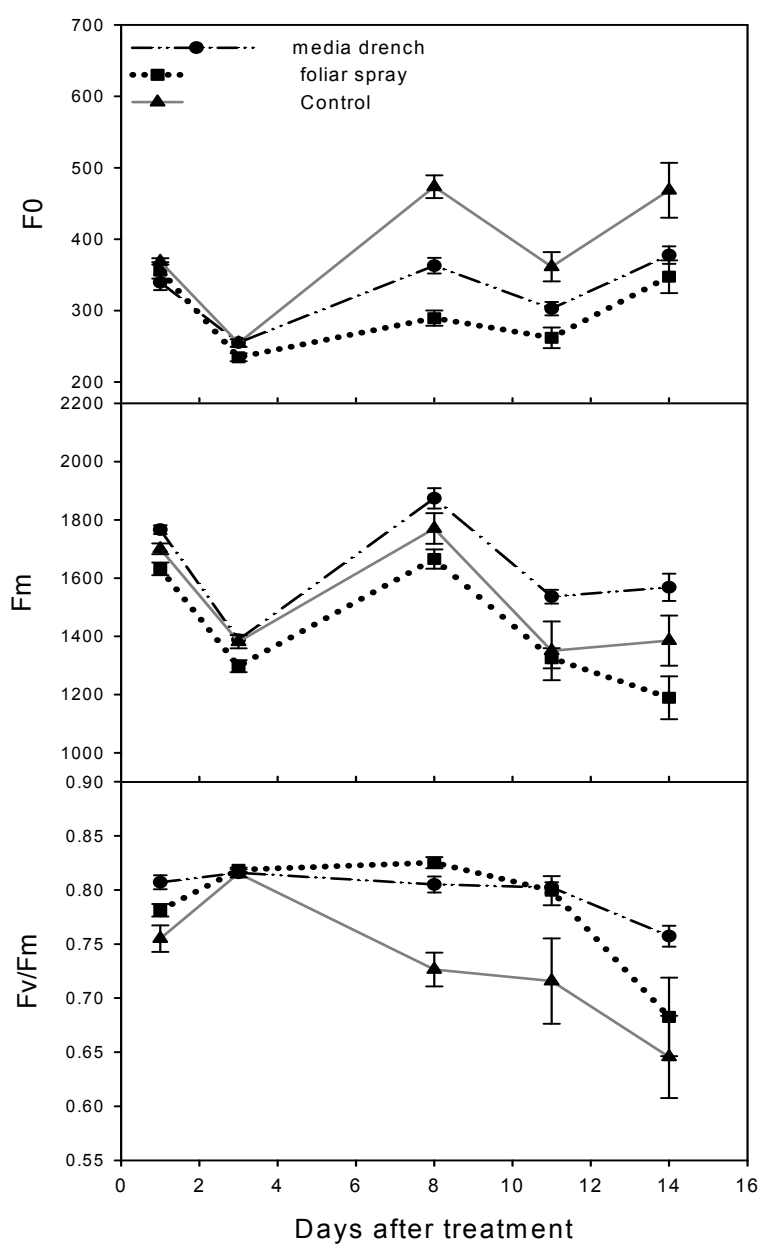

Fig. 4. Effects of $100 \mu \mathrm{M}$ salicylic acid treatment by medium drench or foliar spray on chlorophyll fluorescence of wax begonia plants.

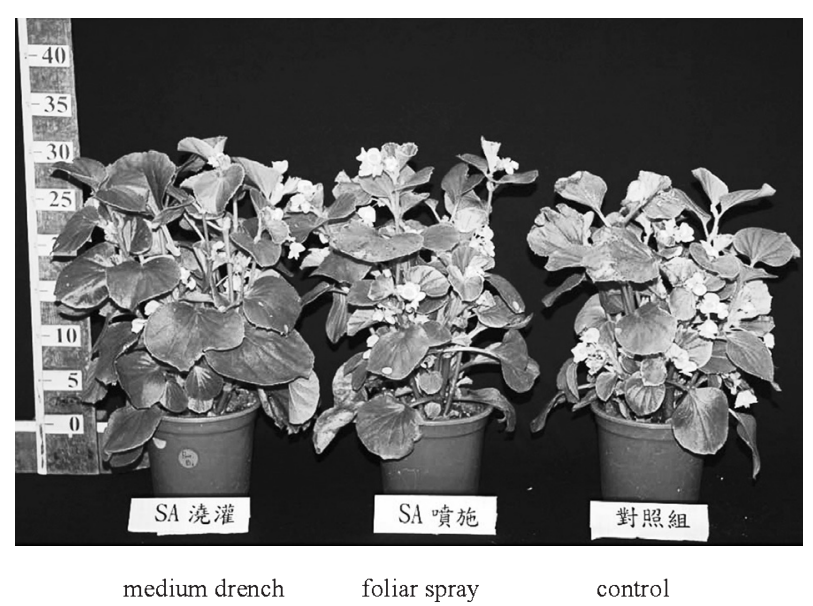

Fig. 5. Effects of $100 \mu \mathrm{M}$ salicylic acid treatment by medium drench or foliar spray on growth status of wax begonia plants after high temperature stress $\left(35 / 30^{\circ} \mathrm{C}\right.$ day/night temperature Phytotron, 14 days). begonia plants under high temperature stress (Fig. 4).

Compared with various applying methods, medium drench showed higher value of $\mathrm{Fm}$ and Fv/Fm. At the end of the test, medium drench showed no leave necrosis and grew more vigorously than foliar spray treatment plants (Figs. 4 and 5).

\section{DISCUSSION}

This study demonstrates that applying satisfactory concentrations (25-400 $\mu \mathrm{M})$ of salicylic acid enhances heat tolerance of wax begonia plug seedlings and transplants, while 800, $1600 \mu \mathrm{M}$ SA treatments had adverse effects (Figs. 1 and 2, Table 1). The results agree with previous research findings in alleviating high temperature stress of mustard plants (Dat et al., 1998a), potato microplants (Lopez et al., 1998), Arabidopsis (Larkindale and Knight, 2002), Cicer arietinum L. (Chakraborty and Tongden, 2005), creeping bentgrass (Larkindale and Huang, 2004), Kentucky bluegrass (He et al., 2005), grape, and Citrus (Wang et al., 2002; 2003).

Plants treated with higher concentrations of SA were often susceptible to stress injury. This is because lower SA doses might induce moderate stress, affecting the oxidative status of the plant similar to stress-acclimation effect (Horváth et al., 2007). However, high exogenous concentrations of SA might cause overly strong oxidative stress for plants to overcome and suffer to death (Kováčik et al., 2009).

Janda (2007) described the primary effect of high temperature is to alter protein conformations and membrane status, indicating that one of the first signs of high temperature stress is reduced a reduction in photosynthetic activity. SA pretreatments helped stabilize the membrane and reduced heat injury, evidenced by the lower value of RI, MDA (Figs. 1 and 2), and the number of leaves with red spots (Table 1). Higher chlorophyll CMR (SPAD-502) value and photochemical efficiency (Fv/Fm) helped plants to maintain photosynthetic activity (Figs. 3 and 4, Table 4).

Results show that both foliar spray and medium drench alleviate heat stress if the doses were lower than $400 \mu \mathrm{M}$ (Table 4). In general, SA treatments were applied by foliar spray (Amutha et al., 2007; Dat et al., 1998a, b; He et al., 2005; Shi et al., 2006; Wang and Li, 2006), and a few studies conducted the medium drench treatment in beans and tomatoes (Senaratna et al., 2000). Results

Table4. Effects of $100 \mu \mathrm{M}$ salicylic acid treatment by medium drench or foliar spray on chlorophyll fluorescence of wax begonia plants at the end of experiment $\left(35 / 30{ }^{\circ} \mathrm{C}\right.$ day/night temperature Phytotron, 14 days after application)

\begin{tabular}{llll}
\hline SA treatment & F0 & Fm & Fv/Fm \\
\hline Control & $468.4 \mathrm{a}^{\mathrm{z}}$ & $1385 \mathrm{ab}$ & $0.646 \mathrm{~b}$ \\
$100 \mu \mathrm{M}$ drench & $377.7 \mathrm{~b}$ & $1568 \mathrm{a}$ & $0.757 \mathrm{a}$ \\
$100 \mu \mathrm{M}$ spray & $347.3 \mathrm{~b}$ & $1189 \mathrm{~b}$ & $0.683 \mathrm{ab}$ \\
\hline
\end{tabular}

Each value is the mean of six replications.

${ }^{2}$ Mean separation within columns by LSD test, $\mathrm{P}<0.05$ 
of this study emphasize that medium drench treatments enhance heat tolerance more than foliar spray treatments do, based on chlorophyll fluorescence parameters during the high temperature period and plant growth performance at the end of the trial (Table 4). The wax texture on the leaf surface of the wax begonia might limit the foliar absorption of salicylic acid. Another possibility is that SA transportation via phloem in the wax begonia might be more efficient than that via xylem. Future study is still needed for advanced research in the future. This study recommends lower concentrations (25$400 \mu \mathrm{M})$ as the medium drench for desired and stable protective effects, or combining medium drench and foliar spray. The concentrations of $100 \mu \mathrm{M}$ of SA proved to be the best protective effect.

This study claims that SA protective effect maintained about five days (Fig. 3, Table 2), and one or two more SA application every 7 days extended protective effect (Table 3). The chlorophyll fluorescence parameters (lower F0 or higher Fv, Fv/Fm) demonstrated temporary significant protective effect. Eraslan (2007) revealed that the long-term effects of SA under stress conditions were not as effective in alleviating abiotic stress as reported in the literature conducted with short-term studies. Results proved that two or three SA applications are more effective than one or no treatment.

In conclusion, salicylic acid pretreatments with satisfactory concentrations between 25 to $400 \mu \mathrm{M}$ enhanced heat tolerance in the wax begonia, whereas treatments applied with 800, $1600 \mu \mathrm{M}$ concentrations had adverse effect. Results recommend the most optimal application of SA treatment as medium drench with $100 \mu \mathrm{M}$ SA per week up to $2-3$ times.

\section{REFERENCES}

Amutha, R., S. Muthulaksmi, W. B. R. K. Indira and P. Mareeswari 2007 Alleviation of high temperature stress in sunflower (Helianthus annus L.) by plant growth regulators and chemicals. Res. J. Agr. Biol. Sci., 3: 1658-1662

Chakraborty, U. and C. Tongden 2005 Evaluation of heat acclimation and salicylic acid treatment as potent inducers of thermotolerance in Cicer arietinum L. Curr. Sci., 89: 384-389

Dat, J. F., H. Lopez-Delgado, C. H. Foyer and I. M. Scott 1998a Parallel changes in $\mathrm{H}_{2} \mathrm{O}_{2}$ and catalase during thermotolerance induced by salicylic acid or heat acclimation in mustard seedlings. Plant Physiol., 116: 1351-1357

Dat, J. F., C. H. Foyer and I. M. Scott 1998b Changes in salicylic acid and antioxidants during induced thermotolerance in mustard seedlings. Plant Physiol., 118: 1455-1461

Eraslan F., A. Inal, A. Gunes and M. Alpaslan 2007 Impact of exogenous salicylic acid on the growth, antioxidant activity and physiology of carrot plants subjected to combined salinity and boron toxicity. Sci. Hortic., 113: 120-128

Hamrick, D. 2003 Ball Redbook. Volume 2. Crop Production. 17th ed. Ball Publishing, Batavia, Illinois (USA) pp. 259-261

Hayat S., B. Ali and A. Ahmad 2007 Salicylic acid: biosynthesis, metabolism and physiological role in plant. In "Salicylic Acid - A plant hormone", ed. by S. Hayat and A. Ahmad, Springer, The Netherlands. pp. 1-14

He, Y. L., Y. L. Liu, W. X. Cao, M. F. Huai, B. G. Xu and B. G. Huang 2005 Effects of salicylic acid on heat tolerance associated with antioxidant metabolism in Kentucky bluegrass. Crop Sci., 45: 988-995

Horváth, E., G. Szalai and T. Janda 2007 Induction of abiotic stress tolerance by salicylic acid signalling. J. Plant Growth Regul., 26: 290-300

Janda, T., E. Horváth, G. Szalai and E. Páldi 2007 Role of salicylic acid in the induction of abiotic stress tolerance. In "Salicylic Acid- A plant hormone", ed. by S. Hayat and A. Ahmad, Springer, The Netherlands. pp. 91-150

Kováčik, J., J. Grúz, M. Bačkor, M. Strnad and M. Repčák 2009 Salicylic acid-induced changes to growth and phenolic metabolism in Matricaria chamomilla plants. Plant Cell Rep., 28: 135-143

Larkindale, J. and B. Huang 2004 Thermotolerance and antioxidant systems in Agrostis stolonifera: Involvement of salicylic acid, abscisic acid, calcium, hydrogen peroxide, and ethylene. J. Plant Physiol., 161: 405-413

Larkindale, J. and M. R. Knight 2002 Protection against heat stress-induced oxidative damage in Arabidopsis involves calcium, abscisic acid, ethylene, and salicylic acid. Plant Physiol., 128: 682-695

Lopez D. H, J. F. Dat and C. H. Foyer 1998 Induction of thermotolerance in potato microplants by acetyl salicylic acid and $\mathrm{H}_{2} \mathrm{O}_{2}$. J. Expt. Bot., 49: 713-720

Senaratna, T., D. Touchell, E. Bunn and K. Dixon 2000 Acetyl salicylic acid (Aspirin) and salicylic acid induce multiple stress tolerance in bean and tomato plants. Plant Growth Regul., 30: 157-161

Shi, Q., Z. Bao, Z. Zhu, Q. Ying and Q. Qian 2006 Effects of different treatments of salicylic acid on heat tolerance, chlorophyll fluorescence and antioxidant enzyme activity in seedlings of Cucumis sativa L. Plant Growth Regul., 48: 127135

Wang, L. J., J. C. Zhan and W. D. Huang 2002 Preliminary study on signal transduction related with salicylic acid during heat acclimation to young grape plants. Chinese Bulletin of Botany, 19: 710-715

Wang, L. J., J. Y. Li, Y. F. Liu, Q. J. Liu, W. D. Huang and Y. L. Shi 2003 Effects of Salicylic acid and $\mathrm{CaCl}_{2}$ on photosynthesis and chlorophyll fluorescence of citrus under heat and drought stress. Chinese Agricultural Science Bulletin, 19: 185-189

Wang, L. J. and S. H. Li 2006 Salicylic acid-induced heat or cold tolerance in relation to $\mathrm{Ca}^{2+}$ homeostasis and antioxidant systems in young grape plants. Plant Sci., 170: 685-694

Yang, J. H., Y. Gao, Y. M. Li, X. H. Qi and M. F. Zhang 2008 Salicylic acid-induced enhancement of cold tolerance through activation of antioxidative capacity in watermelon. Sci. Hortic., 118: 200-205 